\title{
Sosialisasi Edukasi Kegiatan yang Membahayakan Pesawat di Kawasan Keselamatan Operasi Penerbangan Bandara SMB II Palembang
}

\author{
Dwi Candra Yuniar ${ }^{1}$, Bambang Wijaya Putra ${ }^{2}$, Herlina Febiyanti ${ }^{3}$ I Gusti Agung Ayu Mas Oka ${ }^{4}$, \\ M. Syahrul Munir ${ }^{5}$, M. Erawan Destyana ${ }^{6}$, Muhammad Al Hafied ${ }^{7}$, \\ Vania Nadhifa Azzahra ${ }^{8}$, Nabila Azzahra' \\ Politeknik Penerbangan Palembang \\ e-mail: candra@poltekbangplg.ac.id
}

\begin{abstract}
Abstrak
Tujuan dari sosialisasi ini adalah untuk memberikan edukasi kepada masyarakat di sekitar Bandara Sultan Mahmud Badaruddin (SMB) II Palembang mengenai kegiatan yag dapat membahayakan penerbangan, agar hal-hal yang membahayakan penerbangan yang diakibatkan oleh aktifitas masyarakat dapat dihindari. Metode sosialisasi yang digunakan adalah paparan oleh narasumber dan diskusi dengan masyarakat yang tinggal di dekat Bandara SMB II Palembang. Hasil yang diperoleh dari sosialisasi ini adalah para peserta (masyarakat) memahami kegiatan-kegiatan apa saja yang membahayakan pesawat terutama di kawasan keselamatan operasi penerbangan Bandara SMB II Palembang. Kemudian hasil dari sosialisasi telah dipublikasikan pada media sosial Poltekbang Palembang.
\end{abstract}

Kata Kunci: Kegiatan Berbahaya, Kawasan Keselamatan Operasi Penerbangan, Sosialisasi

\begin{abstract}
The purpose of this socialization was to provide education to the people around Sultan Mahmud Badaruddin (SMB) II Palembang Airport about activities that can endanger flights, so that things that endanger flights caused by community activities can be avoided. The socialization method used was exposure by experts and discussions with people living near SMB II Palembang Airport. The results obtained from this socialization are that the participants (community) understand what activities endanger aircraft, especially in the flight operation safety area of SMB II Palembang Airport. The results of the socialization have been published on the Palembang Aviation Polytechnic social media.
\end{abstract}

Keywords: Aviation Operation Safety Area, Dangerous Activities, Socialization

\section{Pendahuluan}

Kondisi covid-19 yang mewabah saat ini menjadikan beberapa perubahan waktu baik di dunia pendidikan maupun dunia kerja. Dampak dari pandemi telah mengubah kebiasaan masyarakat dari yang tidak dilakukan di masa normal menjadi dilakukan di masa pandemi, sekalipun nilai kemanfaatannya terkadang lebih kecil dari potensi bahaya yang ditimbulkan (Buana, 2020; Fitri \& Qismullah, 2021). Pemberlakuan peraturan libur sekolah untuk anak-anak di beberapa sekolah dan pengaturan work from office (WFO) dan work from home (WFH) bagi pekerja juga masih diterapkan. Untuk mengisi waktu luang, berbagai aktivitas dilakukan oleh semua kalangan masyarakat dengan alasan untuk mengusir kebosanaan di rumah. Beragam aktifitas dilakukan mulai dari berkebun, bersepeda hingga berkemah. Salah satu aktifitas masyarakat yang banyak dilakukan juga oleh kalangan anak-anak maupun orang dewasa adalah bermain layang-layang. Bermain layang-layang merupakan permainan tradisional yang sering dimainkan di tanah lapang.

Permainan layang-layang membutuhkan tempat yang lapang dan aman. Namun karena keterbatasan tempat lapang, terkadang tepi jalan raya dan sekitar bandara dijadikan tempat untuk main layang-layang. Namun hal itu tentu saja sangat berbahaya. Di wilayah sisi udara Bandara Ngurah Rai, selama bulan Juni 2020 terdapat 5 laporan insiden layang-layang jatuh. Layang-layang tersebut jatuh di sejumlah titik di sekitar bandara antara lain area runway, taxiway, runway shoulder 
dan apron yang termasuk Kawasan Keselamatan Operasi Penerbangan (KKOP) (Dhae, 2020). Bermain layang-layang di bandara atau di sekitar Kawasan Keselamatan Operasi Penerbangan (KKOP) sangat membahayakan keselamatan penerbangan, karena ada kemungkinan pesawat tertabrak atau menabrak layangan tersebut. Kemungkinan lainya, senar atau benang laying-layang tertarik ke dalam mesin pesawat. Hal ini sangat merugikan penerbangan dan membuat pesawat tidak boleh beroperasi sementara serta harus dilakukan pemeriksaan lebih lanjut. Sehingga kesadaran masyarakat terhadap dampak atau akibat bermain layang-layang di kawasan keselamatan operasi penerbangan tersebut, sangat diperlukan Corporate Communication Senior Manager PT Angkasa Pura I, Awaluddin (Shalihah, 2020).

Undang-Undang Nomor 1 Tahun 2009 tentang Penerbangan, dalam pasal 210 melarang setiap orang berada di daerah tertentu di bandar udara, membuat halangan (obstacle) dan/atau melakukan kegiatan lain di kawasan keselamatan operasi penerbangan yang dapat membahayakan keselamatan dan keamanan penerbangan. Selain itu, sesuai pasal 421 menyebutkan bagi pelanggar dapat dikenakan pidana kurungan selama 3 tahun atau denda sebesar Rp. 1.000.000.000 (Yudhoyono, 2019).

Dalam kegiatan angkutan udara baik penumpang ataupun barang, keselamatan penerbangan merupakan hal yang wajib diperhatikan oleh seluruh stakeholder (pemangku kepentingan). Kesadaran hukum yang baik dari semua pihak sangat diperlukan, untuk mematuhi semua persyaratan dalam mewujudkan keselamatan penerbangan (Purba, 2017). Gerakan nasional penyadaran budaya keselamatan penerbangan (safety culture) diperlukan untuk mewujudkan keselamatan penerbangan. Melalui gerakan budaya keselamatan penerbangan diharapkan dapat memberikan kenyamanan bagi masyarakat. Bertambahnya jumlah maskapai penerbangan menyebabkan bertambah dibukanya rute-rute baru yang semakin banyak potensi bersinggungan dengan kepentingan masyarakat (Aflah \& Zulfi, 2017). Rinaldi et al., (2021) sinergi dari berbagai pihak haruslah dilibatkan dalam memastikan operasi bandara dan kawasan terbang. Untuk menghindari resiko buruk yang mungkin terjadi, peran aktif stakeholder menjadi ujung tombak penting yang aktif.

Dalam rangka turut menjaga keamanan dan keselamatan penerbangan, maka tim Politeknik Penerbangan Palembang melaksanakan sosialiasi tentang Kawasan Keselamatan Operasi Penerbangan kepada masyarakat di sekitar Bandara SMB II Palembang. Sosialisasi dapat diartikan sebagai proses belajar tentang segala sesuatu di dalam kehidupan yang meliputi norma, bahasa, nilai, mata pencaharian, ilmu pengetahuan, sistem kemasyarakatan, agama, kesenian, dan lainnya (Ismail, 2019). Sosialisasi ini bertujuan untuk memberikan pengetahuan dan pemahaman kepada masyarakat umum terutama yang tinggal disekitar Kawasan Keselamatan Operasi Bandara SMB II Palembang sehingga hal-hal yang menjadi penyebab terjadinya gangguan penerbangan tidak terjadi di lingkungan Kawasan Keselamatan Operasi Bandara SMB II Palembang.

\section{Metode}

Kegiatan sosialisai dilakukan di Politeknik Penerbangan Palembang yang berada di Jalan Adi Sucipto, Kecamatan Sukarami, Kota Palembang pada tanggal 30 November 2021. Khalayak sasaran dari kegiatan sosialisasi ini adalah Warga di sekitar Bandara SMB II Palembang yang berjumlah 20 orang. Adapun tahapan dari kegiatan ini terdiri dari persiapan, pelaksanaan dan evaluasi. Dalam tahap persiapan, tim yang terdiri dari dosen dan taruna Program Studi Diploma 3 Manejemen Bandar Udara berkoordinasi dengan Pihak Bandara SMB II Palembang dan Ketua Rukun Tetangga yang berada di sekitar Bandara SMB II, untuk menetapkan peserta yang mengikuti kegiatan sosialisasi ini. Pada tahap persiapan dilakukan juga persiapan ruangan, alat dan bahan serta materi yang akan disampaikan saat sosialisasi. Tahap pelaksanaan dilaksanakan melalui tatap muka langsung dengan tetap memperhatikan protokol kesehatan. Penerapan protokol kesehatan minimal yaitu $3 \mathrm{M}$ (menggunakan masker, mencuci tangan dan menjaga jarak) dapat meningkatkan pencegahan penyebaran virus Covid-19 dan juga dapat meningkatkan kebersihan tubuh untuk 
menghindari berbagai virus yang bisa menyerang tubuh (Winarso, et al., 2020). Tahap evaluasi dilakukan dengan meminta tanggapan para peserta terhadap kegiatan ini.

\section{Hasil dan Pembahasan}

Kegiatan ini dibuat dengan tujuan memberikan sosialisasi sebagai wujud memberikan pelayanan kepada masyarakat dengan harapan mampu membantu masyarakat di lingkungan Bandara Sultan Mahmud Badaruddin II Palembang untuk mengetahui hal-hal yang membahayakan operasional pesawat di Kawasan Keselamatan Operasi Penerbangan. Kegiatan ini dilaksanakan selama satu hari. Pelaksanaan sosialisasi mengundang masyarakat yang tinggal di sekitar KKOP Bandara SMB II Palembang. Penyampaian materi akan dilakukan oleh narasumber yang berasal dari Dosen Politeknik Panerbangan Palembang dilanjutkan dengan diskusi dan Tanya jawab. Keberhasilan sosialisasi selaras dengan hasil yang dicapai Pratiwi (2019) kesadaran hukum masyarakat terhadap keselamatan penerbangan efektif jika dilakukan melalui kegiatan sosialisasi langsung kepada masayarakat.

Dalam rangka penerapan prorokol kesehatan, kegiatan sosialiasi diawali dengan memberikan hand sanitizer kepada setiap peserta yang mengikuti kegiatan sosialiasi. Para peserta juga selalu dihimbau untuk menjaga jarak $\pm 1 \mathrm{~m}$ antar peserta dan untuk selalu memakai masker sesuai dengan protokol kesehatan yang dianjurkan oleh pemerintah, yang didokumentasikan dapat dilihat berikut ini.

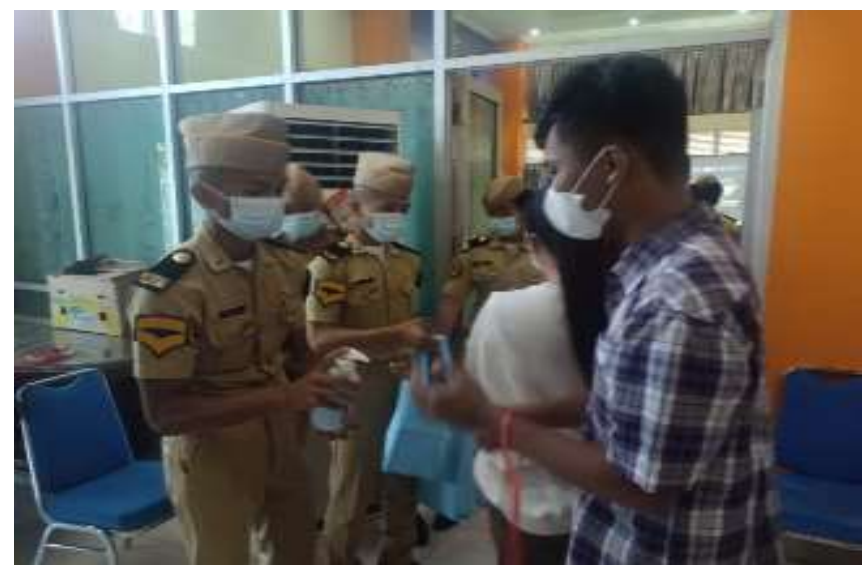

Gambar 1. Pembagian Hand Sanitizer

Kegiatan dilanjutkan dengan pemaparan dan penyampaian materi, diskusi dan tanya jawab. Adapun meteri yang disampaikan diawali dengen pemaparan tentang dasar-dasar hukum pengendalian benda tumbuh dan bergerak di KKOP, yang meliputi Undang-Undang Nomor 1 Tahun 2009 tentang Penerbangan khususnya pasal 202, 206, 208, 210 dan 421 (Yudhoyono, 2019). Peraturan Menteri Perhubungan Nomor KM 44 tahun 2005 tentang Pemberlakuan Standar Nasional Indonesia (SNI) 03-7112-2005 Mengenai Kawasan Keselamatan Operasi Penerbangan yang mengatur bahwa KKOP terdiri dari Kawasan pendekatan dan lepas landas, kemungkinan bahaya kecelakaan, di bawah permukaan horizontal dalam, di bawah permukaan horizontal luar, di bawah permukaan kerucut dan di bawah permukaan transisi (Rajasa, 2005). Peraturan Menteri Perhubungan Nomor PM 41 Tahun 2011 tentang Organisasi dan Tata Kerja Kantor Otoritas Bandar Udara pasal 3 yang menyatakan bahwa Kantor Otoritas Bandar Udara menyelenggarakan fungsi salah satunya adalah pelaksanaan pengaturan, pengendalian, dan pengawasan penggunaan KKOP dan Daerah Lingkungan Kerja (DLKr) serta Daerah Lingkungan Kepentingan Bandar Udara (DLKP) (Numberi, 2011). Dokumentasi kegiatan penyampaian dan pemaparan materi dapat dilihat pada gambar berikut. 


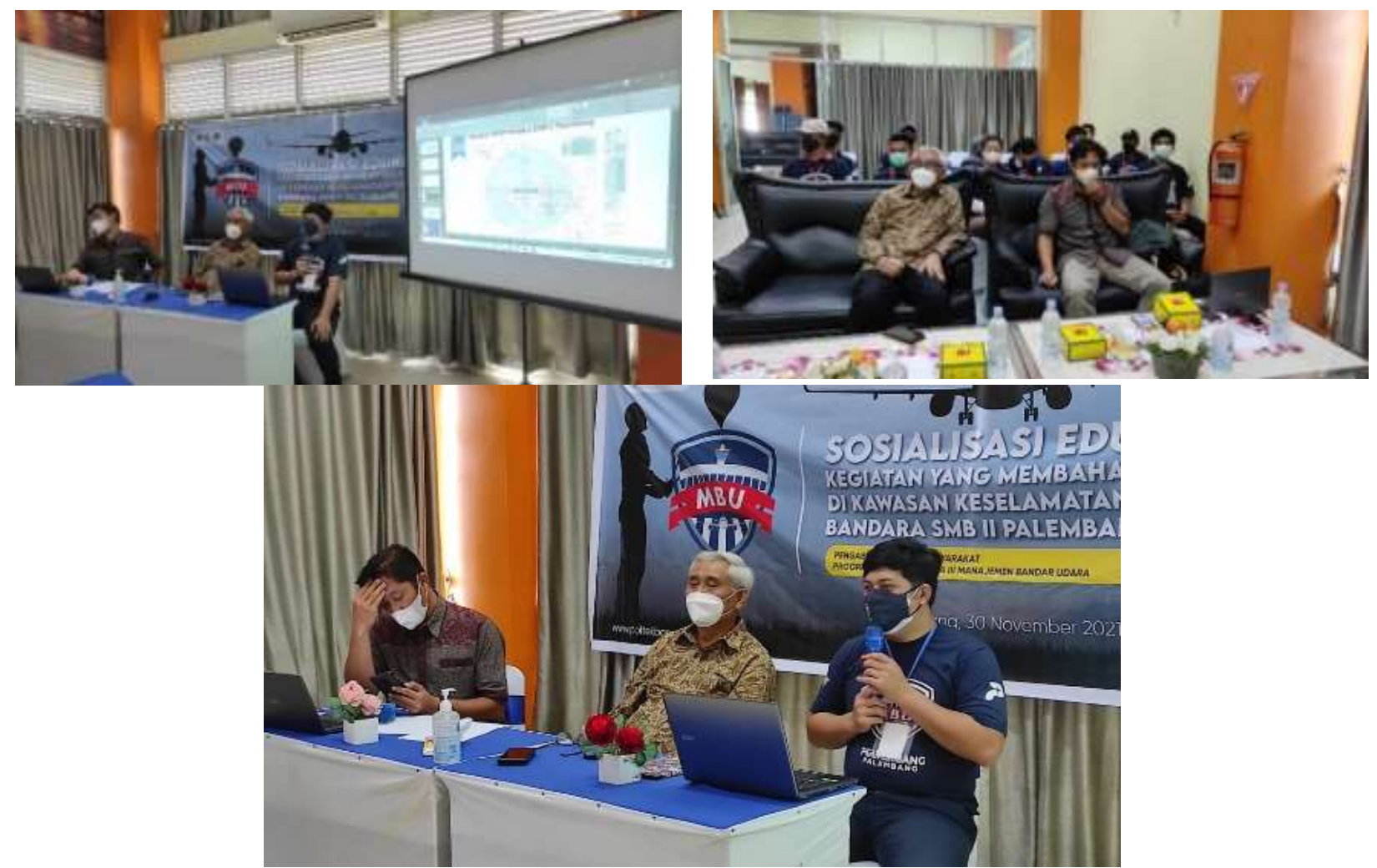

Gambar 2. Dokumentasi Pemaparan Materi

Kegiatan dilanjutkan dengan tanya jawab dan diskusi, serta tes tulis. Bagi peserta yang aktif bertanya dan menjawab, serta yang mendapatkan nilai terbaik diberikan hadiah berupa door prize. Seluruh peserta dinyatakan telah memahami materi yang diberikan, berdasarkan hasil penilaian tes tulis dengan hasil sebagai berikut:

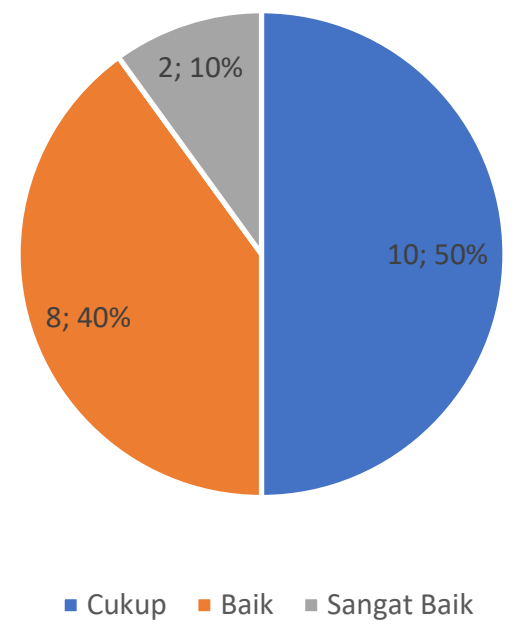

Gambar 3. Hasil Evaluasi

Para peserta juga diberikan kesempatan untuk memberikan masukan dan saran sebagai bagian dari evaluasi kegiatan. Proses penilaian yang dilaksanakan untuk memperoleh gambaran tentang keberhasilan suatu kegiatan disebut evaluasi(Anwar, 2021). Evaluasi pendidikan dapat juga diartikan sebagai kegiatan dalam mengumpulkan data dan informasi tentang kemampuan belajar peserta didik, dan untuk menilai sejauh mana program telah berjalan. Selain itu evaluasi merupakan suatu alat untuk menentukan apakah tujuan pendidikan telah berlangsung sebagaimana mestinya 
(Idrus, 2019). Dari masukan dan saran yang diberikan para peserta menyatakan sosialiasi yang diberikan sangat bermanfaat dan agar para dosen lebih sering mengadakan kegiatan sosialisasi ini, sehingga masyarakat sekitar bandara dapat turut berperan serta dalam membantu menjaga keselamatan dan keamanan penerbangan. Kegiatan diakhiri dengan acara penutupan dan foto bersama yang didokumentasikan berikut ini.

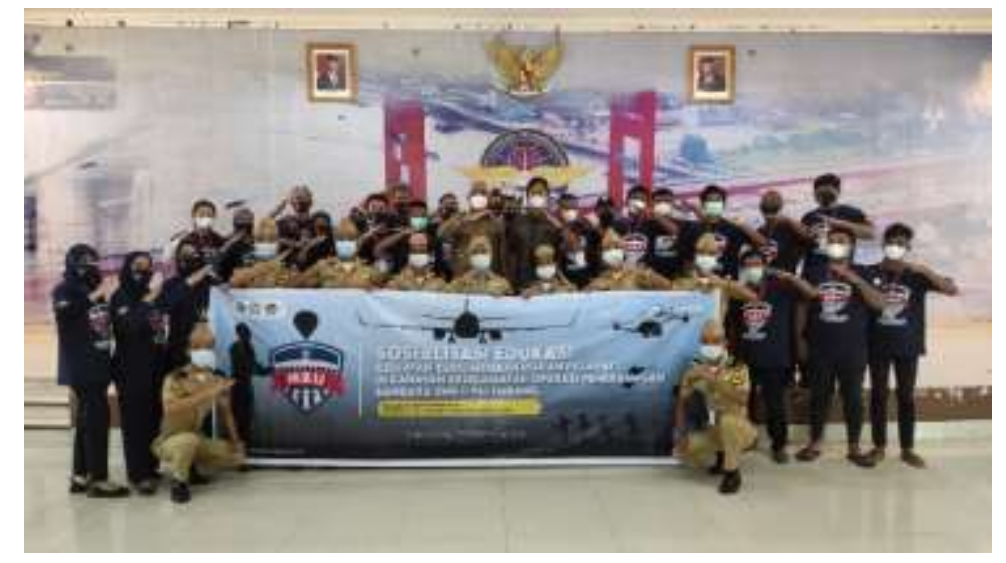

Gambar 4. Foto Bersama

\section{Kesimpulan}

Dari pelaksanaan kegiatan sosialisasi ini dapat disimpulkan bahwa masyarakat dapat memahami tentang kegiatan yang membahayakan operasional pesawat di Kawasan Keselamatan Operasi Penerbangan, dan diharapkan agar masyarakat turut berperan aktif dalam menjaga keselamatan dan keamanan penerbangan. Adapun saran yang penulis berikan diantaranya kegiatankegiatan serupa di wilayah lain sangat perlu dilakukan, untuk meningkatkan kesadaran masyarakat terhadap keselamatan dan keamanan di Kawasan Keselamatan Operasi Penerbangan (KKOP). Selain itu perlu dijalin kerjasama dengan instansi-instansi pemerintah, swasta maupun industri agar kegiatan sosialisasi mengenai KKOP dapat berlanjut ke seluruh wilayah di sekitar Bandar Udara.

\section{Daftar Pustaka}

Aflah, \& Zulfi, C. (2017). Tanggung Jawab Air Navigation dalam Pelayanan Lalu Lintas Udara untuk Keselamatan Penerbangan. Mimbar Hukum, 29(1), 1-15.

Anwar, K. (2021). Urgensi Evaluasi Dalam Proses Pembelajaran. Rausyan Fikr: Jurnal Pemikiran \& Pencerahan, 17(1), 108-117.

Buana, D. R. (2020). Analisa Perilaku Masyarakat Indonesia dalam Menghadapi Pandemi Virus Corona (Covid-19) dan Kiat Menjaga Kesejahteraan Jiwa. Salam: Jurnal Sosial dan Budaya Syar-I, 7(3), 217-226.

Dhae, A. (2020, Juli 8). Retrieved November 15, 2021, from www.mediaindonesia.com: https://mediaindonesia.com/nusantara/326637/bandara-ngurah-rai-tertibkan-layang-layangdi-ruang-udara-bandara

Fitri, K., \& Qismullah, F. I. (2021). Analisis Perilaku Masyarakat Indonesia Dalam Menghadapi Pandemi Virus Corona (Covid-19) dan Kiat Menjaga Kesejahteraan Jiwa. Jurnal Riset dan Pengabdian Kepada Masyarakat, 1(1), 95-110. doi:https://doi.org/10.22373/jrpm.v1i1.666

Idrus, L. (2019). Evaluasi Dalam Proses Pembelajaran. ADAARA: Jurnal Manajemen Pendidikan Islam, 9(2), 920-935.

Ismail. (2019). Pentingnya Sosialisasi Bagi Anak (Studi Kajian Sosiologi Pendidikan). Jurnal Ilmiah Sosiologi Agama (JISA), 2(1), 27-41.

Numberi, F. (2011, Maret 31). Peraturan Menteri Perhubungan Republik Indonesia Nomor PM 41 Tahun 2011 tentang Organisasi dan Tata Kerja Kantor Otoritas Bandar Udara. 
Pratiwi, R. (2019). Pengawasan Penerbangan Balon Udara pada Kegiatan Budaya Masyarakat Berdasarkan Pasal 11 Peraturan Menteri Perhubungan Nomor 40 Tahun 2018 tentang Penggunaan Balon Udara pada Kegiatan Budaya Masyarakat. Novum: Jurnal Hukum, 6(3), 46-55.

Purba, H. (2017). Mewujudkan Keselamatan Penerbangan dengan Membangun Kesadaran Hukum bagi Stakeholders melalui Penerapan Safety Culture. Jurnal Hukum Samudra Keadilan, 12(1), 95-100.

Rajasa, M. H. (2005, Juli 23). Peraturan Menteri Perhubungan Republik Indonesia Nomor KM 44 Tahun 2005 tentang Pemberlakukan Standar Nasional (SNI) 03-7112-2005 Mengenai Kawasan Keselamatan Operasi Penerbangan Sebagai Standar Wajib.

Rinaldi, R., Prasetyo, I., Rifki, A., \& Ikhwanul, Q. (2021). Sosialisasi Kawasan Keselamatan Operasional Penerbangan Pada Masyarakat Kecamatan Cluring, Banyuwangi. Tekiba: Jurnal Teknologi dan Pengabdian, 1(1), 7-9.

Shalihah, N. F. (2020, Juli 22). Retrieved November 2021, 15, from www.kompas.com: https://www.kompas.com/tren/read/2020/07/22/170500265/larangan-bermain-layanglayang-di-bandara-berbahaya-hingga-bisa-kena-denda?page =all

Winarso, S., Prastyantoko, K., Dhanny, P., Elia, Y., Ogis, P., \& Rizqi, A. (2020). Penerapan Protokol Kesehatan Covid-19 di Era New Normal Pada Kampung Tanggung Desa Karangdoro, Terminal Jajag, dan RTH Maron Genteng, Kabupaten Banyuwangi. Multidisciplinary Journal, 3(1), 25-33.

Yudhoyono, S. B. (2019, Januari 12). Undang-Undang Republik Indonesia Nomor 1 Tahun 2009 Tentang Penerbangan. 